\title{
ПРАВОВА ПРИРОДА ПУБЛІЧНОГО АДМІНІСТРУВАННЯ У ДІЯЛЬНОСТІ ОРГАНІВ ДЕРЖАВНОЇ ВИКОНАВЧОЇ ВЛАДИ
}

\begin{abstract}
Протягом останніх десятиліть в Україні відбувається активний процес реформування виконавчої влади. Однак, як показує вітчизняний досвід, позитивні результати трансформаційних змін у діяльності державних органів неможливо очікувати лише внаслідок простого запозичення зарубіжного досвіду, скорочення чисельності посадовців, зміни переліку органів державної виконавчої влади або перерозподілу їніх повноважень. У цьому сенсі необхідно концептуально змінити підходи до роботи органів виконавчої влади та державних службовців. Водночас під час проведення наукового аналізу основ функціонування органів державної виконавчої влади відбувається поступовий перехід від акценту на парадигмі «державне управління» до парадигми «публічне адміністрування». Усе більшого поширення в наукових роботах та посібниках набуває використання таких понять, як «публічне управління», «публічне адміністрування», «публічна адміністрація», поряд із «державним управлінням» та «органом державної виконавчої влади». Окрім того, галузь знань «публічне управління та адміністрування» включено до галузей знань і спеціальностей, за якими здійснюється підготовка здобувачів вищої освіти [1]. Проте у чинному законодавстві та працях науковців відсутнє однозначне визначення поняття «публічне адміністрування». Це негативно впливає на проведення державно-управлінських реформ в Україні,
\end{abstract}

спрямованих на впровадження прогресивних та якісних змін у системі публічної влади в Україні. Викладені обставини зумовлюють актуальність дослідження.

Питання визначення та сутності публічного адміністрування розглядалися у роботах В.Б. Авер'янова, Е.А. Афоніна, М.М. Білинської, А.Ф. Колодія, Б.А. Кормича, В.В. Круглова, А.А. Пухтецької, С.С. Серьогіна та інших науковців. Останнім часом окремі аспекти публічного адміністрування у різних сферах досліджувалися у дисертаціях Д.Л. Ворон «Правові засади публічного адміністрування у сфері вищої освіти» (2018р.) [2], А.В. Хрідочкіна «Публічне адміністрування у сфері інтелектуальної власності в Україні» (2019р.) [3], I.П. Яковлєва «Форми і методи публічного адміністрування у державній митній справі» [4]. Однак здобутки вчених не замінюють відсутність комплексного дослідження концепції публічного адміністрування у сфері виконавчої влади, не вирішують існуючих спірних питань у визначеннях понятійно-категоріального апарату та співвідношення публічного адміністрування iз суміжними поняттями, що є перешкодою до практичної реалізації процесу реформування органів виконавчої влади в Україні відповідно до згальновизнаних європейських стандартів.

Метою статті є дослідження поняття та сутності публічного адміністрування у діяльності органів державної вико- 
навчої влади для з'ясування можливості практичного реформування сфери діяльності виконавчої влади відповідно до нових тенденцій розвитку адміністративно-правової доктрини.

Концепція публічного адміністрування у вітчизняній науці не $є$ новою, але має ознаки динамічного розвитку, що грунтується на зарубіжному досвіді ii розуміння. У зв'язку із цим зауважимо, що сьогодні існують три основні конкуруючі між собою у теоретичному та практичному аспектах концепції розуміння публічного адміністрування.

1. Ринково-ліберальна - це сформульований на концептуальних моделях нового менеджменту, оновленого публічного адміністрування, активного впровадження у діяльність органів публічної влади інструментів та технологій, що використовуються у приватних бізнес-структурах тощо. При цьому для споживачів послуг важливим $€$ результат, а не способи його досягнення. Тому питання соціального захисту стають другорядними.

2. Ліберально-комунітаристська розвивається в концепції політичних мереж. За такого підходу структурні відносини, що формуються між політичними інститутами держави, громадськими організаціями й окремими громадянами, є договірними, тобто вони взаємодіють як рівноправні партнери.

3. Демократичного громадянства характеризується положеннями концепції «рецептивного (сприйнятливого) адміністрування», «партисипативного (що бере участь) менеджменту», базовими принципами яких $є$ надійність та цілісність формування політики, участь громадян, централізація та децентралізація, відкритість .і прозорість, високі етичні стандарти. Їх реалізація створює умови для кардинальних змін у взаємовідносинах між органами влади та місцевого самоврядування, їх службовцями і громадянами. Окрім того, висуваються нові вимоги до публічних адміністрацій та їхньої діяльності [5, с. 5-6; 6, с. 15].

Ураховуючи викладене, публічне адміністрування як об'єкт наукового пізнання дає змогу дослідити характер відносин між особами та суб'єктами публічної адміністрації у процесі виконання останніми покладених на них законом адміністративних зобов'язань. Сьогодні в науковій літературі існують декілька концептуальних підходів до визначення змісту «публічного адміністрування». По-перше, це загальне розуміння публічного адміністрування як частини політичного процесу у діяльності всіх гілок державної влади. Таке визначення кореспондується з даними, наданими у глосарії Програми розвитку $\mathrm{OOH}$, за якою публічне адміністрування має два тісно пов'язаних значення: 1) цілісний державний апарат (політика, правила, процедури, системи, організаційні структури, персонал тощо), який фінансується з державного бюджету й відповідає за управління та координацію роботи виконавчої гілки влади і його взаємодію з іншими заінтересованими сторонами в державі, суспільстві й зовнішньому середовищі; 2) управління та реалізація всього комплексу державних заходів, пов'язаних із виконанням законів, постанов і рішень уряду та управлінням у сфері надання публічних послуг [7]. Убачається, що такий підхід не дасть змоги встановити практичне значення та конкретну спрямованість публічного адміністрування на задоволення публічного інтересу у відносинах «суспільство - публічна влада», з'ясувати конкретні сфери та його напрями, що $є$ необхідним для застосування нової, більш ефективної методології управління для підвищення ефективності діяльності публічної адміністрації. У цьому сенсі більш обгрунтованим $є$ інший (більш вузький та функціонально спрямований) підхід, за яким публічне адміністрування розуміється як окрема форма діяльності суб'єктів публічного адміністрування, до яких відносяться й органи державної виконавчої влади. Ця точка зору набула достатньо широкого схвалення серед науковців. Так, Ю.П. Битяк визначає публічне адміністрування як регламентовану законами та іншими 
нормативно-правовими актами діяльність суб'єктів публічного адміністрування, спрямовану на здійснення законів та інших нормативно-правових актів шляхом прийняття адміністративних рішень, надання встановлених законами адміністративних послуг [8, с. 7]. Характеризуючи публічне адміністрування як форму реалізації публічної влади, окремі дослідники відзначають, що публічне адміністрування характеризується: 1) зовнішнім виразом реалізації завдань (функцій) виконавчої влади; 2) адміністративною діяльністю публічної адміністрації; 3) метою - задоволення публічного інтересу; 4) негативним відмежовуванням від законодавчої діяльності, здійснення правосуддя, політичної діяльності виконавчої влади, а також діяльності, спрямованої на задоволення приватних інтересів. При цьому вони роблять висновок, що публічне адміністрування як форма реалізації публічної влади - це адміністративна діяльність суб'єктів публічної адміністрації, яка $€$ зовнішнім виразом реалізації завдань (функцій) виконавчої влади, що здійснюється з метою задоволення публічного інтересу й негативно відмежовується від законодавчої судової та політичної діяльності [9, с. 19-20].

На думку B.K. Колпакова, зміст публічного адміністрування становить діяльність суб'єкта публічної адміністрації, що спрямована на виконання владних повноважень публічного змісту й яка використовує засоби управління, надання адміністративних послуг, участь у відносинах відповідальності суб'єктів публічної адміністрації, застосування заходів впливу за порушення правил, установлених публічною адміністрацією [10]. Автори дисертаційних досліджень останніх років щодо проблем публічного адміністрування у контексті специфічних об'єктів правовідносин (зокрема, С.В. Сівков, О.О. Навроцький, Є.Є. Чернецький, I.П. Яковлєв) наголошують на ключових параметрах досліджуваного явища саме як регламентованої нормативно-правовими актами підзаконної діяль- ності органів державної виконавчої влади.

Підтримуючи вузьке розуміння публічного адміністрування, сутність публічного адміністрування відносно функціонування органів державної виконавчої влади можливо охарактеризувати крізь призму їхньої діяльності, яка спрямована на реалізацію або виконання законодавчих та інших нормативно-правових актів для досягнення мети публічного адміністрування. Останньою є, з одного боку, задоволення публічного інтересу, насамперед інтересу держави, суспільства та громади під час виконання державними органами своїх владних управлінських функцій, а з іншого - публічне адміністрування пов'язане із задоволенням важливих індивідуальних потреб окремої особи, зокрема в отриманні адміністративних послуг.

Як наслідок, до основних сфер, якими охоплюється зміст публічного адміністрування, у діяльності органів державної виконавчої влади можливо віднести такі.

По-перше, розпорядчу діяльність органів державної виконавчої влади щодо прийняття нормативних актів, спрямованих на реалізацію або виконання законодавчих актів, у межах нормативно визначеної компетенції.

По-друге, адміністрування адміністративних послуг. У цьому розумінні адміністрування є не лише діяльністю 3 розроблення внутрішніх правил та режиму надання адміністративних послуг конкретним органом виконавчої влади, а й включає у себе контрольну та наглядову діяльність за процедурою ї надання.

По-третє, безпосереднє надання адміністративних послуг органами державної виконавчої влади.

По-четверте, прийняття адміністративних актів (рішень) та контроль над ї реалізацією. Адміністративним актом (рішенням) виступає у цьому разі рішення індивідуальної дії, прийняте суб'єктом публічного адміністрування, спрямоване на набуття, зміну, припи- 
нення чи реалізацію прав або обов'язків особи (осіб).

По-п'яте, внутрішню діяльність указаних суб'єктів публічного адміністрування, за допомогою якої забезпечується сама можливість його здійснення (структурування штату, документообіг, кадровий набір, розпорядження фінансовими ресурсами).

Убачається, що цей підхід буде підданий критичній оцінці з позиції недоцільності включення до спектру характеристик, не властивих публічному адмініструванню. Однак таке трактування сфер публічного адміністрування у діяльності органів державної виконавчої влади не буде надмірно широким та має на меті забезпечити правовий захист, зокрема отримувачів адміністративних послуг, від зловживань посадовців. Окрім того, зауважимо, що публічне адміністрування $€$ комплексним поняттям, яке неможливо ототожнювати з державним управлінням.

Розглянемо один із прикладів існуючих практичних проблемних питань, які доводять, що до складників публічного адміністрування доцільно віднести адміністрування адміністративних послуг та відповідну внутрішньоорганізаційну діяльність органів державної виконавчої влади. Так, до надання адміністративних послуг у розумінні чинного законодавства належить надання територіальними органами Державної служби України з питань праці (далі - Держпраця) дозволів на виконання робіт підвищеної небезпеки, експлуатації (застосування) машин, механізмів, устаткування підвищеної небезпеки шляхом реєстрації декларації відповідності матеріально-технічної бази вимогам законодавства 3 питань охорони праці. Порядок видачі дозволів на виконання робіт підвищеної небезпеки та на експлуатацію (застосування) машин, механізмів, устаткування підвищеної небезпеки затверджений Постановою Кабінету Міністрів України від 26.10.2011 № 1107 [11] (далі - Порядок). Ідеологія останніх змін 2020 р., які були внесені до
Порядку, полягала у наданні можливості виконувати суб'єктам господарювання більшість робіт з об'єктами підвищеної небезпеки на підставі подання декларації безпеки об'єктів підвищеної небезпеки. Відповідно до п. 21 зазначеного Порядку [11], декларація подається роботодавцем, виробником або постачальником, уповноваженою ним особою або надсилається поштою до територіального органу Держпраці або адміністратора центру надання адміністративних послуг у паперовій формі або в електронній формі через Єдиний державний вебпортал електронних послуг, у тому числі через інтегровану 3 ним інформаційну систему Держпраці. Територіальний орган Держпраці здійснює реєстрацію декларацій на безоплатній основі протягом п’яти робочих днів зі дня їх отримання. При цьому відмова в реєстрації декларації не допускається. Результатом надання такої адміністративної послуги виступає реєстрація відповідної декларації відповідності матеріально-технічної бази вимогам законодавства з питань охорони праці у журналі обліку суб'єктів господарювання у відповідному органі Держапраці, що посвідчується проставленням відмітки на примірнику декларації про дату на номер іiі реєстрації. Можна зробити висновок, що у такому разі під час надання адміністративної послуги відсутні відносини влади та підпорядкування, властиві державному управлінню у його «класичному» розумінні, оскільки фактично резюмується відсутність надання обов'язкових для виконання приписів із боку державного органу. Маємо закріплену в технологічній картці адміністративної послуги порядок іiі надання, що зумовлюється взаємодією суб'єкта господарювання, заінтересованого в отриманні такої послуги, та суб'єкта публічного адміністрування. Проте сьогодні численними $€$ випадки повернення попередньо поданих, наприклад через центри надання адміністративних послуг до територіальних органів Держпраці, декларацій про відповідність 
матеріально-технічної бази вимогам законодавства з питань охорони праці. Наприклад, на сайті Головного управління у Київській області міститься перелік незареєстрованих декларацій за 2020 р., інформація про підстави нереєстрації яких не зазначена [12]. При цьому Державна регуляторна служба України неодноразово звертала увагу на численні випадки фактичної відмови у реєстрації декларацій органами Держпраці, що спричиняє виникнення напруги у стосунках суб'єктів господарювання і дозвільних органів та створює перешкоди для діяльності суб'єктів господарювання. Підставами для відмови у реєстрації декларацій зазначаються відсутність інформації про наявність договору страхування цивільної відповідальності перед третіми особами стосовно відшкодування наслідків можливої шкоди, інформаціі про кожне місце виконання робіт, заповнення пунктів «не в повному обсязі», що не передбачено законом тощо [13].

Іноді у змісті повернутих без реєстрації декларацій містяться відмітки про факт заповнення декларацій із порушенням установлених вимог. 3 ї змісту неможливо встановити посаду чи дані особи, яка здійснила цей запис, також відсутня печатка державного органу. Офіційна публікація зареєстрованих декларацій на сайті Держпраці також не вирішила проблему з безпідставним поверненням декларацій про відповідність матеріально-технічної вимогам законодавства 3 питань охорони праці. Тому заінтересована в отриманні адміністративної послуги особа, якій фактично повернули без реєстрації декларацію, попередньо прийняту центром надання адміністративних послуг, має вирішити питання, які ефективні інструменти захисту прав, свобод та інтересів у сфері публічного адміністрування можна використати у цьому разі. У ст. 19 Закону України «Про адміністративні послуги» від 06.09.2012 № 5203-VI [14] закріплено загальну норму щодо оскарження дій або бездіяльності посадових осіб, упов- новажених відповідно до закону надавати адміністративні послуги, до суду або в порядку, встановленому законом. У такому разі застосування адміністративних (квазісудових) засобів правового захисту у відносинах з органом Держпраці буде малоефективним, адже відсутній чіткий, затверджений на нормативному рівні, алгоритми адміністрування цієї адміністративної послуги, порядок та строки розгляду скарг або звернення особи щодо оскарження дій, рішень або бездіяльності для захисту законних інтересів особи, а також можливі рішення за наслідками розгляду такої скарги. Затверджений на виконання Закону України «Про звернення громадян» від 06.09.2012 № 5203-VI [15] Наказ Міністерства соціальної політики України від 16.11.2016 № 1339 [16], що визначає порядок розгляду звернень та організації особистого прийому громадян у Держпраці та іï територіальних органах, цю проблему не вирішує. Отже, найбільш ефективним, хоча й довготривалим, засобом захисту інтересів особи є звернення до суду з позовною заявою в порядку, передбаченому КАС України [17]. Хоча у цьому разі розгляд адміністративної справи може тривати більше року, не враховуючи час набрання судовим рішенням законної сили та час його фактичного виконання суб'єктом публічного адміністрування.

Публічне адміністрування в діяльності органів державної виконавчої влади - це нормативно передбачена діяльність органів державної виконавчої влади, яка має організаційний та розпорядчий зміст, спрямована на виконання законів та інших нормативно-правових актів із метою задоволення публічного інтересу: ухвалення адміністративних актів (рішень), надання адміністративних послуг, адміністрування надання адміністративних послуг та внутрішне упорядкування діяльності органами державної виконавчої влади, за допомогою якої забезпечується можливість здійснення публічного адміністрування. Зауважимо, що за сучасних умов одним 
із недоліків $є$ неврахування на нормативному рівні необхідності детальної регламентації процедурних форм реалізації прав та обов'язків учасників у відносинах, які складаються в публічному адмініструванні, що призводить до фактичної безвідповідальності посадовців за неналежне виконання покладених на них обов'язків.

Перспективним напрямом наукових досліджень є подальше концептуальне переосмислення діяльності органів державної виконавчої влади крізь призму публічного адміністрування, що дасть змогу визначити стратегічні напрями й орієнтири реформування сфери виконавчої влади та отримати якісно нову модель відносин між громадянами та публічною владою.

Статтю присвячено аналізу питань поняття та сутності публічного адміністрування в діяльності органів державної виконавчої влади. Проаналізовано різні погляди вітчизняних учених щодо розуміння публічного адміністрування, які базуються на зарубіжному досвіді. Наголошено, шо з метою встановлення практичного значення та конкретної спрямованості публічного адміністрування $i$ задоволення публінного інтересу його слід розглядати як форму діяльності суб'єктів публічного адміністрування, до яких відносяться й органи державної виконавчої влади. Вказано, що до сфер, якими охоплюється зміст публічного адміністрування, можна віднести розпорядчу діяльність щзодо прийняття нормативних актів, спрямованих на реалізацію або виконання законодавчих актів, у межах нормативно визначеної компетенцї; адміністрування адміністративних послуг; безпосередне надання адміністративних послуг; прийняття адміністративних актів (рішень) та контроль над їх реалізацією; внутрішню діяльність суб'єктів публінного адміністрування, за допомогою якої забезпечується можливість здійснення публічного адміністрування. Відзначено, що неврахування всіх складників $є$ перешкодою до забезпечення наленного правового захисту отримувачів адміністративних послуг, що з'ясовано на прикладі реєстрації територіальними органами Держпращі деклараизї відповідності матеріально-технічної бази вимогам законодавства з питань охорони праці. Зроблено висновок, щзо публічне адміністрування в діяльності органів державної виконавчої влади - ие нормативно передбачена діяльність органів державної виконавчої влади, яка має організаційний та розпорядчий зміст, спрямована на виконання законів та інших нормативно-правових актів із метою задоволення публічного інтересу.

Ключові слова: публічне адміністрування, орган державної виконавчої влади, адміністративна послуга, адміністрування, публічна влада.

Zhuravel Ya. Legal nature of public administration in the activities of state executive agencies

the article is focused on the analysis of the concept and essence of public administration in the activities of state executive agencies. Different points of view of national scholars on the understanding of public administration based on international experience have been analyzed. It has been emphasized that public administration should be considered as a form of activity of public administration entities, which include state executive agencies in order to establish the practical significance and specific orientation of public administration to meet the public interests. It has been indicated that the areas covering the content of public administration may include administrative activities for the adoption of regulatory acts aimed at the implementation or execution of legislative acts within the 
normative competence; administration of administrative services; direct provision of administrative services, adoption of administrative acts (decisions) and control over their implementation; internal activities of public administration entities, through which the possibility of public administration is provided. It has been noted that failure to take into account all components is an obstacle to ensure the proper legal protection of recipients of administrative services, which is clarified by the example of registration of declaration of the compliance of logistics with the requirements of labor protection legislation by the territorial State Labor agencies. It has been concluded that public administration in the activities of state executive agencies is normatively provided activity of state executive agencies, which has organizational and administrative content, aimed at executing laws and other regulatory actns in order to meet public interests.

Key words: public administration, state executive agency, administrative services, administration, public power.

\section{Література}

1. Про затвердження переліку галузей знань $і$ спеціальностей, за якими здійснюється підготовка здобувачів вищої освіти : Постанова Кабінету Міністрів України від 29.04.2015 № 266. URL : https: / / zakon.rada.gov.ua/laws / show/ru/ 266-2015-\% D0\% BF\#Text.

2. Ворон Д.Л. Правові засади публічного адміністрування у сфері вищої освіти : дис. ... канд. юрид. наук : 12.00.07. Ужгород, 2018. URL : https: / / www.uzhnu.edu.ua/ uk/infocentre/get/ 18117.

3. Хрідочкін А.В. Публічне адміністрування у сфері інтелектуальної власності в Україні : дис. ... канд. юрид. наук : 12.00.07. Запоріжжя, 2019. $508 \mathrm{c.}$

4. Яковлев І.П. Форми $і$ методи публічного адміністрування у державній митній справі: дис.... канд. юрид. наук: 12.00.07. Одеса, 2016. URL : http://dspace.onua.edu.ua/ handle/11300/5318.

5. Ястремська О.М., Мажник Л.О. Публічне адміністрування : навчаль- ний посібник. Харків : ХНЕУ ім. С. Кузнеия, 2015. 132 c.

6. Кошелева Л.Е. Основні теоретичні підходи до визначення публічного адміністрування. Державне управління та місцеве самоврядування 2018. Bun. 2(37). C. 13-18.

7. Definition of basic concepts and terminologies in governance and public administration: note by the Secretariat. URL : https: / / digitallibrary.un.org / record/566603.

8. Основи публічного адміністрування : посібник для підготовки до іспиту / Ю.П. Битяк та ін. Харків : Право, 2016. 128 с.

9. Адміністративне право України. Повний курс : підручник / В. Галунько та ін. Херсон : ОЛДІ-ПЛЮС, 2018. 446 с.

10. Колпаков В.К. Адміністративноправові відносини: поняття $i$ види. Юридичний науковий електронний журнал. 2013. № 1. C. 101-104. URL : http:// www.lsej.org.ua.

11. Порядок видачі дозволів на виконання робіт підвищеної небезпеки та на експлуатаиію (застосування) машин, механізмів, устатковання підвищеноі небезпеки : Постанова Кабінету Міністрів України від 26.10.2011 № 1107. URL : https://zakon.rada.gov.ua/laws/ show / 1107-2011-\% D0\% BF.

12. Адміністративні послуги / Головне управління Держпраці у Київській області. URL : http://kiev.dsp.gov.ua/ administratyvni-poslugy/.

13. Щодо реєстраціі декларацій / Державна регуляторна служба України. URL : http://www.drs.gov.ua/permit_ system / shhodo-reyestratsiyi-deklaratsij/.

14.Про адміністративні послуги Закон України від 06.09.2012 № 5203-VI. URL : https://zakon.rada.gov.ua/laws/ show/5203-17\#Text.

15. Про звернення громадян : Закон України від 02.10.1996 № 393/96-ВP. URL : https: //zakon2.rada.gov.ua/laws / show $/ 393 / 96-\%$ D0\% B2\% D1\% 80\#Text.

16. Про затвердження порядку розгляду звернень та організації особистого прийому громадян у Державній службі Украіни з питань праці та ї територіальних органах : Наказ Міністерства соціальної політики України від 16.11.2016 № 1339. URL : https://zakon.rada.gov.ua/laws / show / z1595-16\#Text.

17. Кодекс адміністративного судочинства України від 06.07.2005 № 2747-IV. URL : https: / / zakon.rada.gov.ua/laws / show/2747-15\#Text. 